\title{
Growth, damage and net nitrogen uptake in Picea abies (L.) Karst. seedlings, effects of site preparation and fertilisation
}

\author{
Fredrik NORDBORG*, Urban NILSSON \\ Swedish University of Agricultural Sciences, Southern Swedish Forest Research Centre, PO Box 49, 23053 Alnarp, Sweden
}

(Received 24 June 2002; accepted 17 February 203)

\begin{abstract}
The effects of four different soil treatments and two different fertilising regimes on growth, nitrogen uptake and damage of planted Picea abies seedlings were studied on abandoned farmland in southern Sweden. Intensive site preparation, i.e. deep soil cultivation of the whole plot area, effectively managed to increase seedling growth and reduce seedling damage during establishment. Inversion of the soil profile in patches and field vegetation control with herbicides did not increase seedling growth and survival as effectively as complete deep soil cultivation, but had both higher growth and survival than the untreated control. Seedling nitrogen uptake was higher in the cultivated treatments and nitrogen uptake was positively correlated to fast root development during the first growing season, but the nitrogen uptake was not correlated to nitrogen net mineralisation. Fertilising increased the amounts of field vegetation. Moreover, seedling damage by voles was correlated to the amount of field vegetation, and seedling damage lowered the seedling growth. The risk for nitrogen leaching is probably higher in complete deep soil cultivation than in other treatments.
\end{abstract}

nitrogen mineralisation / Norway spruce / root growth / seedling establishment / nitrogen leaching

Résumé - Effets de travaux de préparation de sol et de la fertilisation sur la croissance, la fréquence de dommages et le prélèvement net d'azote des plants de Picea abies (L.) Karst. On a étudié les effets de quatre types de préparation du sol et de deux régimes de fertilisation sur la croissance, la consommation d'azote et la fréquence de dommages de plants de Picea abies installés dans des terrains agricoles abandonnés du Sud de la Suède. Une préparation intensive du sol, c'est-à-dire un labour profond sur l'ensemble de la surface, se traduit effectivement par un accroissement de la croissance des plants et une réduction des dommages subis pendant la période d'installation. Un retournement partiel du sol et le contrôle de la végétation par herbicides se révèlent moins efficaces qu'un travail profond du sol en plein, mais donnent des résultats supérieurs à ceux observés dans les parcelles témoins. La consommation d'azote par les plants est plus élevée dans les parcelles cultivées et cette consommation est corrélée positivement avec un développement rapide des racines pendant la première saison de végétation. Mais la consommation d'azote n'est pas corrélée avec le taux de minéralisation nette. La fertilisation entraîne un développement plus important de la végétation basse. De plus, l'importance des dégâts dus aux mulots est corrélée à celle de la végétation basse et les dommages causés aux plants réduisent leur croissance. Le risque de perte d'azote par lessivage est probablement plus grand avec un travail du sol profond et en plein que pour les autres traitements.

minéralisation de l'azote / épicéa commun / croissance racinaire / installation des plants / lessivage de l'azote

\section{INTRODUCTION}

Establishment of seedlings on fertile sites may be difficult since they contain dense field vegetation. The field vegetation competes with the seedlings for resources such as water, light and nutrients [13, 17, 21]. Moreover, the field vegetation provides protection to damaging agents (e.g. voles). The damage causes higher mortality resulting in lower seedling densities, and also lowers initial seedling growth [1]. Field vegetation control with herbicides and soil scarification has been proved to increase initial growth and decrease damage for newly planted seedlings $[10,13,27]$. Deep soil cultivation has increased initial seedling growth and decreased seedling damage [22]. However, soil profile inversion in patches has also shown promising results on initial growth, but experiments have not yet been carried out on fertile sites with much vegetation in Sweden [30]. Field vegetation control with herbicides is regularly used in farmland afforestation and several studies have shown increased growth after field vegetation removal $[1,19,23,24,41]$, but since the competition mainly is for resources below ground, mowing is not sufficient [24]. Although all site preparation methods mentioned above have been proven efficient, there is still a need for additional studies that compare the methods.

\footnotetext{
* Corresponding author: Fredrik.Nordborg@ess.slu.se
} 
Nitrogen is the limiting plant nutrient in most forest ecosystem in Sweden [40]. Despite the abundance of nitrogen on a clear-felled site [12], nitrogen availability is low, something which limits the growth of newly planted seedlings [20]. Seedlings have access to little nitrogen after clear-felling as a result of competition with the field vegetation [24]. Moreover, according to results, seedling growth during the second growing season is positively correlated to the seedling net uptake of nitrogen during the first growing season after planting [1, 25]. Fast and early root growth for newly planted seedlings is decisive to nutrient and water uptake, and root growth results both in better root soil contact and greater soil exploitation [3, 5, 15]. Root growth is restricted by high soil densities, drought and low soil temperatures $[6,11,27,34]$. Since soil scarification increases the soil water availability, reduces the soil density and increases the soil temperature, it is often positive to root growth [9, 27, 35]. By controlling the field vegetation with herbicides and soil scarification, the competition for nitrogen may decrease [19, 21, 24, 34]. The soil temperature may also be positively affected by field vegetation control [41].

Site preparation may increase nitrogen loss, and this may be a problem to ground water quality and reduce future site fertility $[14,28]$. Therefore, it is necessary to develop methods that promote survival and high seedling growth with a low risk of nitrogen leaching.

In this study, effects on seedling survival, growth and net nitrogen uptake were evaluated in three site preparations and two fertiliser regimes. The aim was to confirm the following hypotheses: (i) site preparation increases seedling initial growth and reduces damage during the first year after planting in planted Norway spruce (Picea abies (L.) Karst.) seedlings, (ii) seedling growth is increased in site preparations with high nitrogen uptake, (iii) site preparation increases net mineralisation, increases root growth and reduces competition from field vegetation, and hence increases seedling nitrogen uptake, (iv) fertilising positively affects seedling growth when field vegetation is controlled, but the effect is negative with uncontrolled vegetation, (v) increased nitrogen mineralisation and reduced amounts of field vegetation increase the risk of nitrogen leaching.

\section{MATERIALS AND METHODS}

The experiment was carried out on abandoned farmland that had lain fallow for eight years. It was situated about $15 \mathrm{~km}$ east of Falkenberg in the southwest of Sweden $\left(56^{\circ} 57^{\prime} \mathrm{N}, 12^{\circ} 42^{\prime} \mathrm{E}\right)$. The soil was a fertile sediment soil with sandy texture, and rich in silt and clay. The topsoil was $30 \mathrm{~cm}$ deep and previously cultivated, and the boundary between top- and subsoil was therefore distinct. The subsoil was rich in ferrous oxides and relatively poor in organic matter.

The experimental design consisted of four randomised blocks with four site preparations as main plots $(12 \times 22 \mathrm{~m})$, which were divided into two subplots (fertilised and unfertilised respectively and $6 \times 22 \mathrm{~m}$ ). A fence for protection against browsing animals surrounded the whole experimental area.

The site preparations were: yearly field vegetation control with herbicides (FVC), complete deep soil cultivation (CDSC), deep soil cultivation in patches (PDSC) and untreated control (C). In FVC, the entire plot was treated with herbicides in the autumn every year and the treatment started the year before the experiment was planted. The active ingredients were $720 \mathrm{~g}$ of glyphosate and $510 \mathrm{~g}$ of terbutylazine per hectare and treatment occasion. In CDSC, the soil profile in the entire plot was inverted down to $60 \mathrm{~cm}$ with an excavator, and the topsoil was buried with 10 to $20 \mathrm{~cm}$ of subsoil material. The treatment was carried out in the middle of April, one month before planting. In PDSC, the treatment was equal to the CDSC but carried out in patches, $90 \mathrm{~cm}$ in diameter, with two-by-two meter spacing (centre to centre). The plots were fertilised (fertilised subplots are abbreviated with $\mathrm{F}$ and unfertilised subplots are abbreviated with NF) in May and August every year with a solid fertiliser. In August 1999, fertilising was not done due to a minor drought period, and when the drought ceased it was too late for fertilising. The fertiliser consisted of $20 \% \mathrm{~N}$ $\left(9.3 \% \mathrm{NO}_{3}^{-}-\mathrm{N}\right.$ and $\left.10.7 \% \mathrm{NH}_{4}^{+}-\mathrm{N}\right), 3 \% \mathrm{P}, 5 \% \mathrm{~K}, 4 \% \mathrm{~S}, 3.4 \% \mathrm{Mg}$ and $0.15 \% \mathrm{~B}$. On each fertilising occasion, $200 \mathrm{~kg}$ per ha of the fertiliser $\left(=40 \mathrm{~kg} \mathrm{~N} \mathrm{ha}^{-1}\right)$ was evenly spread over the subplot.

Three-year-old (1.5/1.5) bare-rooted Norway spruce seedlings were used in the experiment and the seeds originated from the Maglehem seed orchard. The seedlings were planted on 11 to 14 May 1998. The spacing between the seedlings was $1 \times 1.5 \mathrm{~m}$ in all treatments except PDSC where the spacing was $2 \times 2 \mathrm{~m}$, equal to the spacing between patches.

The seedling height and stem/base diameter were recorded directly after planting and then during dormancy each year for three growing seasons. Three additional measurements of current-year shoot length and stem/base diameter were carried out during the first season after planting on six seedlings per plot to be used in the calculations of nitrogen uptake. The degree of damage caused by frost, voles, competing vegetation, pine weevil, and the most severe of other damage agents were recorded on all measurement occasions. The degree of damage was recorded using a six-level scale, where 0 was undamaged, 1 was slightly damaged, ..., 4 was severely damaged, and 5 was dead. In further analyses, 1 and 2 were merged to a class called "slightly damaged" and 3 and 4 to "severely damaged". Between the first and second growing season, voles caused severe damage in the experiment. The surviving seedlings were therefore protected against future damage from voles with about $25 \mathrm{~cm}$ long plastic tubes (commercial stem protection devices for fruit trees) wrapped around the stem base.

Two seedlings per treatment and block (in all 64 seedlings) were harvested during dormancy for three growing seasons and on two additional occasions during the first growing season after planting. The seedlings were randomly chosen within four size classes. The seedlings were carefully excavated and the roots washed under running water and dried at $70{ }^{\circ} \mathrm{C}$ for $48 \mathrm{~h}$. The biomass of the following seedling fractions were determined: current-year needles, currentyear twigs, older needles, older twigs + stem and root. The nitrogen concentration in the seedling fractions was determined using a Carlo Erba NA1500 elemental analyser (Carlo Erba Strumentazione, Milan, Italy). The biomass of the seedlings remaining in the plot was calculated based on data from the harvested seedlings, using a set of regression functions. First, the total above-ground biomass was determined with $d^{2} h$ as independent variable, where $d$ was root collar diameter and $\mathrm{h}$ was seedling height. Then, the biomass of roots and total current-year shoots were calculated with total above-ground dry weight as independent variable. The biomass of current-year needles was determined with total current-year shoot as independent variable. The biomass of older (i.e. older than the current year) above-ground parts was attained by subtracting the total above-ground dry weight from the total current-year shoot dry weight. The biomass of older needles was determined with total older shoot dry weight as independent variable. Indicator variables were used to separate between treatments (soil treatment and fertilising) in all regressions. The regression functions had an $\mathrm{r}^{2}$ between 0.7 and 0.9 . One regression function was used to determine the total above-ground biomass during each growing season, but the different seedling fractions were 
determined through regressions for each harvest. The nitrogen content for individual seedlings was calculated by multiplying the average nitrogen concentration for each fraction and treatment with the calculated biomass.

The amount of field vegetation in F and NF in CDSC, FVC and C was estimated through destructive harvesting of all living field vegetation above ground within two $0.25 \mathrm{~m}^{2}$ sample plots per plot. The sample plot was positioned between the excavated seedling and a neighbouring seedling, and the distance was random. The vegetation samples were dried at $70^{\circ} \mathrm{C}$ for $48 \mathrm{~h}$ prior to weighing. The vegetation samples were taken in late June/early July and late August in 1998, 1999 and 2000. Since there was only a small and not significant difference between early and late harvest, the two samplings were treated as two repetitions in further analyses.

The soil water potentials 10,30 and $50 \mathrm{~cm}$ below the soil surface were measured on two occasions per growing season (late spring and late summer) when drought was expected (low precipitation and/or decreasing soil water potentials in other experiments with more intensive monitoring) and using gypsum blocks (Soil Moisture Inc., USA). Three gypsum blocks at the three different levels were installed at the centre of the F subplot in all main plots. Gypsum blocks were also installed in the NF subplot in the $\mathrm{C}$ treatment at 10 and $30 \mathrm{~cm}$ depth in order to evaluate the effect of fertilising.

The amount of exchangeable inorganic nitrogen $\left(\mathrm{NO}_{3}^{-}\right.$and $\left.\mathrm{NH}_{4}^{+}\right)$ was estimated in the soil, and the net mineralisation and potential nitrification were determined according to the In-Situ-Soil-Core method [32]. Samplings were taken in NF and F within CDSC, FVC and $\mathrm{C}$ in every block. One soil core (diameter $=3 \mathrm{~cm}$ ) to 30 or $50 \mathrm{~cm}$ depth was taken in every treatment and block. On the same occasion, a PVC tube was driven to $30 \mathrm{~cm}$ depth in the soil 10 to $15 \mathrm{~cm}$ from this core and the aperture was covered from precipitation. The soil was divided into two levels, $0-10 \mathrm{~cm}$ and $10-30 \mathrm{~cm}$ respectively, prior to the analysis of the amount of inorganic nitrogen. On some occasions, inorganic nitrogen was estimated between 30 and $50 \mathrm{~cm}$ soil depth (but mineralisation was not determined at this depth). The soil was incubated in the tube for $1 \frac{1}{2}$ to 2 months except for an incubation period during the winter season when the soil was incubated for approx. 8 months. At all incubations, composite samples were made over the blocks, except on the first occasion when variations between the blocks were studied. The composite samples were homogenised and sieved through a 2-mm sieve before they were frozen at $-20{ }^{\circ} \mathrm{C}$ and stored until analysis. Thirty grams of the homogenised and sieved soil sample was thawed and extracted in $75 \mathrm{~mL} 1 \mathrm{M}$ $\mathrm{KCl}$ under natural moisture conditions, and then shaken for two hours. The soil was extracted within four hours after thawing to avoid changes in inorganic nitrogen content or form in the soil sample in comparison to unfrozen samples [7]. Ammonia and nitrate amounts in the extracts were quantified using a flow injection analyser (FIA) (Tecator 5012, Höganäs, Sweden). In order to determine net $\mathrm{N}$ mineralisation and potential nitrification, the amounts of inorganic nitrogen in the soil in the PVC tubes after incubation were subtracted from the amounts in the soil taken at the time when incubation was initiated. The soil density was determined with cylinders, which were $80 \mathrm{~mm}$ in diameter and $100 \mathrm{~mm}$ long. The sampling levels were $0-10,10-20$, 20-30, 30-40 and 40-50 cm below the mineral soil surface, respectively. Density sampling was performed in one soil pit per plot in CDSC, FVC and C (since FVC and C did not differ, the results from these treatments were merged in the analysis). The sampling levels $0-10$, 10-20 and 20-30 $\mathrm{cm}$ were replicated twice per plot.

In the spring 1999, one ceramic suction lysimeter (P80) was installed per soil treatment in each block (in unfertilised plots). The lysimeter was installed at the centre of the plot at $60-65 \mathrm{~cm}$ soil depth, i.e. below the main part of the root zone and below the deepest soil treatment. Sampling was made in autumn, winter and spring whereas no soil water could be extracted in the summer. Sampled water was frozen at $-20{ }^{\circ} \mathrm{C}$ until analysis. The total nitrogen content was analysed according to the Kjeldahl method (Technicon Ind Meth 376-75W/B and Technicon Ind Meth 695-82W mod, Tarrytown, New York, USA) and $\mathrm{NO}_{3}-\mathrm{N}$ was analysed in an ion chromatograph (EPA method 300.0) and $\mathrm{NH}_{4}-\mathrm{N}$ was analysed using an FIA (Tecator ASN 50-05/90, Höganäs, Sweden).

The results were tested statistically through the Analysis of Variance using a General Linear Model for split-plot models (SAS ${ }^{\circledR}$ Inst.) with soil treatment as main plot and fertilising as subplot. Differences between individual treatments were evaluated with Tukey's significant difference mean separation test if the effect of the soil treatment was significant $(p<0.05)$. Frequencies of damaged and dead seedlings were arcsine square root-transformed prior statistical test [42].

\section{RESULTS}

Both seedling height and diameter growth were positively affected by soil scarification (Fig. 1). The diameter for CDSC and PDSC was significantly greater than FVC and $\mathrm{C}$ after the first growing season and also after the third growing season. The height difference between soil treatments became significant after the third growing season and CDSC was significantly higher than FVC and C. The current-year shoot growth was higher in PDSC than in other soil treatments during the first growing season, and during the second season there were no differences. However, during the third growing season current-year shoot growth in CDSC was significantly larger than in other soil treatments (data not shown). Fertilising did not affect diameter, height or current-year shoot growth, but there was interaction between soil treatment and fertilising after the third year (data not shown). Seedlings in PDSC were taller in fertilised plots but opposite results were found in other soil treatments.

In both $\mathrm{F}$ and NF, seedling biomass was significantly greater in CDSC and PDSC compared to $\mathrm{C}$ and FVC two months after planting. It remained so until after the second growing season when the seedling biomass in CDSC was greater than in all other soil treatments and $\mathrm{C}$ had less biomass than other treatments (Tab. I). After three growing seasons all soil treatments were significantly different and the ranking was $\mathrm{CDSC}>\mathrm{PDSC}>\mathrm{FVC}>\mathrm{C}$. There was significant interaction between soil treatment and fertilising. Throughout the experiment, fertilising affected seedling biomass increase negatively in $\mathrm{C}$, but in other treatments the effect of fertilising varied in time. During the first growing season fertilising did not affect the seedling biomass in FVC and CDSC, while growth was negatively affected during the second and third growing seasons. In PDSC, there was a positive fertilising effect on seedling biomass from the end of the first growing season until the experiment ended.

In all treatments, the current-year shoot biomass increased evenly between planting and the beginning of September during the first growing season, while most of the root biomass increase occurred between July and September (Tab. I). In both $\mathrm{F}$ and $\mathrm{NF}$, during the first growing season the root growth was higher in the soil-scarified treatments CDSC and PDSC than in FVC and $\mathrm{C}$. The current-year shoot biomass increase was also higher in CDSC and PDSC than in FVC and $\mathrm{C}$ during the first growing season for both $\mathrm{F}$ and NF. At the end of the year, all soil treatments were significantly different (CDSC > $\mathrm{PDSC}>\mathrm{FVC}>\mathrm{C}$ ) in both $\mathrm{F}$ and NF. During the following 

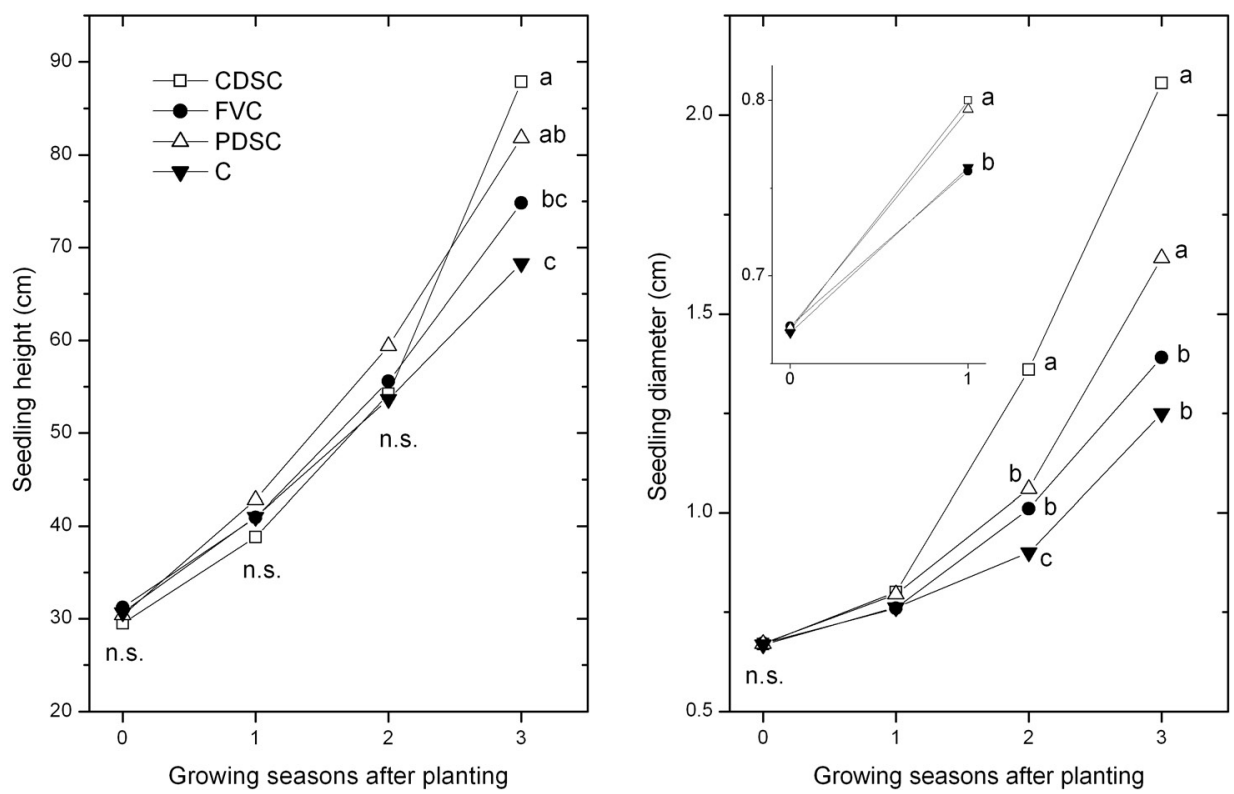

Figure 1. Seedling height and diameter development. Statistically significant differences between treatments are shown with different letters $\mathrm{CDSC}=$ complete deep soil cultivation, $\mathrm{FVC}=$ field vegetation control, $\mathrm{PDSC}=$ deep soil cultivation in patches and $\mathrm{C}=$ control.

Table I. Seedling dry weight $(\mathrm{g})$ in the different treatments during the three growing seasons. $\mathrm{C}=$ control; FVC = field vegetation control; $\mathrm{PDSC}=$ patch deep soil cultivation and $\mathrm{CDSC}=$ complete deep soil cult. $\mathrm{NF}=$ non fertilisation and $\mathrm{F}=$ fertilisation. Soil treatment with different letters in italic were significantly different in statistical test. No statistically significant effect of fertilization was found. $\mathrm{N}=$ number of seedlings that are the base for the calculation.

\begin{tabular}{|c|c|c|c|c|c|c|c|c|c|c|c|c|}
\hline \multirow[b]{3}{*}{ Total seedling weig } & \multicolumn{3}{|c|}{$\mathrm{C}$} & \multicolumn{3}{|c|}{ FVC } & \multicolumn{3}{|c|}{ PDSC } & \multicolumn{3}{|c|}{ CDSC } \\
\hline & $\mathrm{F}$ & \multicolumn{2}{|l|}{$\mathrm{NF}$} & $\mathrm{F}$ & \multicolumn{2}{|l|}{$\mathrm{NF}$} & $\mathrm{F}$ & \multicolumn{2}{|l|}{$\mathrm{NF}$} & $\mathrm{F}$ & \multicolumn{2}{|l|}{$\mathrm{NF}$} \\
\hline & & & & & & & & & & & & \\
\hline May 201998 & 14.8 & 15.5 & $a$ & 17.8 & 16.2 & $a$ & 15.4 & 17.0 & $a$ & 14.7 & 15.7 & $a$ \\
\hline July 21998 & 17.1 & 19.7 & $c$ & 20.8 & 18.9 & $b$ & 21.4 & 21.7 & $a$ & 19.2 & 20.0 & $a$ \\
\hline Sept. 71998 & 15.7 & 18.6 & $c$ & 23.8 & 21.8 & $b$ & 27.5 & 27.9 & $a$ & 26.9 & 27.7 & $a$ \\
\hline March 171999 & 19.3 & 20.9 & $b$ & 21.6 & 21.2 & $b$ & 28.5 & 25.3 & $a$ & 28.4 & 27.1 & $a$ \\
\hline March 312000 & 28.1 & 35.5 & $c$ & 58.6 & 65.9 & $b$ & 65.7 & 56.8 & $b$ & 102.7 & 102.7 & $a$ \\
\hline Nov. 172000 & 64.7 & 81.4 & $d$ & 96.9 & 124.0 & $c$ & 173.5 & 138.2 & $b$ & 232.6 & 261.7 & $a$ \\
\hline \multicolumn{13}{|l|}{ Root weight } \\
\hline May 201998 & 4.0 & 4.2 & $a$ & 4.8 & 4.3 & $a$ & 4.1 & 4.5 & $a$ & 3.9 & 4.2 & $a$ \\
\hline July 21998 & 3.6 & 4.0 & $c$ & 3.9 & 3.6 & $c$ & 4.9 & 5.0 & $a$ & 4.2 & 4.3 & $b$ \\
\hline Sept. 71998 & 5.5 & 6.4 & $b$ & 6.9 & 6.5 & $b$ & 8.8 & 8.1 & $a$ & 9.6 & 9.1 & $a$ \\
\hline March 171999 & 6.3 & 6.7 & $b$ & 6.8 & 6.7 & $b$ & 8.9 & 8.1 & $a$ & 8.6 & 8.2 & $a$ \\
\hline March 312000 & 8.4 & 10.5 & $c$ & 16.7 & 18.7 & $b$ & 18.8 & 16.3 & $b$ & 33.3 & 33.3 & $a$ \\
\hline Nov. 172000 & 16.6 & 20.4 & $c$ & 21.6 & 27.8 & $c$ & 43.9 & 35.9 & $b$ & 55.9 & 62.5 & $a$ \\
\hline \multicolumn{13}{|c|}{ Current year shoot weight } \\
\hline May 201998 & 0.0 & 0.0 & $a$ & 0.0 & 0.0 & $a$ & 0.0 & 0.0 & $a$ & 0.0 & 0.0 & $a$ \\
\hline July 21998 & 1.8 & 2.4 & $d$ & 3.9 & 3.6 & $c$ & 4.6 & 4.7 & $b$ & 5.3 & 5.5 & $a$ \\
\hline Sept. 71998 & 2.9 & 3.8 & $d$ & 4.3 & 4.0 & $c$ & 8.6 & 8.0 & $a$ & 7.7 & 7.4 & $b$ \\
\hline March 171999 & 2.9 & 3.3 & $d$ & 4.6 & 4.5 & $c$ & 6.9 & 6.0 & $b$ & 8.4 & 8.0 & $a$ \\
\hline March 312000 & 6.6 & 9.2 & $c$ & 16.3 & 18.8 & $b$ & 19.9 & 16.9 & $b$ & 29.6 & 29.6 & $a$ \\
\hline Nov. 172000 & 14.6 & 19.1 & $d$ & 26.7 & 34.1 & $c$ & 46.2 & 36.6 & $b$ & 65.4 & 73.3 & $a$ \\
\hline $\mathrm{N}$ & 39 & 52 & & 120 & 164 & & 60 & 65 & & 215 & 231 & \\
\hline
\end{tabular}


Table II. Seedling nitrogen content and concentration in the different treatments during the three growing seasons. $\mathrm{C}=$ control; $\mathrm{FVC}=$ field vegetation control; $\mathrm{PDSC}=$ patch deep soil cultivation and $\mathrm{CDSC}=$ complete deep soil cultivation, $\mathrm{NF}=$ non fertilisation and $\mathrm{F}=$ fertilisation . Soil treatment with different letters in italic were significantly different in statistical test. Fert. column shows significance levels from statistical test $($ n.s. $=$ not significant, $*=$ significant at 0.05 level), $\mathrm{N}=$ number of seedlings that are the base for the calculation.

\begin{tabular}{|c|c|c|c|c|c|c|c|c|c|c|c|c|c|}
\hline & \multicolumn{3}{|c|}{$\mathrm{C}$} & \multicolumn{3}{|c|}{ FVC } & \multicolumn{3}{|c|}{ PDSC } & \multicolumn{3}{|c|}{ CDSC } & \multirow[b]{2}{*}{ Fert. } \\
\hline & $\mathrm{F}$ & $\mathrm{NF}$ & & $\mathrm{F}$ & $\mathrm{NF}$ & & $\mathrm{F}$ & NF & & $\mathrm{F}$ & NF & & \\
\hline \multicolumn{14}{|c|}{ Seedling nitrogen content $(\mathrm{g})$} \\
\hline May 201998 & 0.19 & 0.20 & $a$ & 0.23 & 0.21 & $a$ & 0.20 & 0.22 & $a$ & 0.19 & 0.20 & $a$ & n.s. \\
\hline July 21998 & 0.18 & 0.18 & $c$ & 0.23 & 0.19 & $b$ & 0.23 & 0.25 & $a$ & 0.22 & 0.21 & $b$ & n.s. \\
\hline Sept. 71998 & 0.21 & 0.23 & $c$ & 0.28 & 0.24 & $b$ & 0.34 & 0.26 & $a$ & 0.37 & 0.23 & $a$ & $*$ \\
\hline March 171999 & 0.21 & 0.22 & $d$ & 0.24 & 0.24 & $c$ & 0.35 & 0.27 & $b$ & 0.38 & 0.34 & $a$ & * \\
\hline March 312000 & 0.35 & 0.44 & $c$ & 0.82 & 0.91 & $b$ & 0.82 & 0.76 & $b$ & 1.34 & 1.41 & $a$ & n.s \\
\hline Nov. 172000 & 0.68 & 0.91 & $d$ & 1.07 & 1.38 & $c$ & 1.88 & 1.46 & $b$ & 2.43 & 2.51 & $a$ & n.s \\
\hline \multicolumn{14}{|c|}{ Seedling nitrogen concentration (\%) } \\
\hline May 201998 & 1.29 & 1.29 & $a$ & 1.29 & 1.29 & $a$ & 1.29 & 1.29 & $a$ & 1.29 & 1.29 & $a$ & n.s. \\
\hline July 21998 & 1.23 & 1.12 & $a$ & 1.30 & 1.14 & $a$ & 1.10 & 1.20 & $b$ & 1.07 & 0.99 & $b$ & $*$ \\
\hline Sept. 71998 & 1.24 & 1.19 & $a$ & 1.31 & 1.15 & $a$ & 1.19 & 1.00 & $b$ & 1.31 & 0.86 & $b$ & $*$ \\
\hline March 171999 & 1.07 & 1.01 & $c$ & 1.11 & 1.17 & $b$ & 1.25 & 1.01 & $b$ & 1.37 & 1.23 & $a$ & $*$ \\
\hline March 312000 & 1.24 & 1.22 & $c$ & 1.39 & 1.36 & $a$ & 1.24 & 1.34 & $b$ & 1.29 & 1.37 & $a b$ & n.s \\
\hline Nov. 172000 & 1.03 & 1.08 & $b$ & 1.10 & 1.11 & $a$ & 1.08 & 1.05 & $b$ & 1.05 & 0,96 & $c$ & n.s \\
\hline $\mathrm{N}$ & 39 & 52 & & 120 & 164 & & 60 & 65 & & 215 & 231 & & \\
\hline
\end{tabular}

two years the root and current-year shoot biomass followed the same pattern as seedling biomass (Tab. I). There was a significant interaction effect on root or current-year shoots between soil treatment and fertilising, which followed the same pattern as for seedling biomass.

The seedling net nitrogen uptake during the first growing season after planting was the highest in CDSC and the lowest in $\mathrm{C}$, where the nitrogen uptake was negligible (Tab. II). The seedling nitrogen content at the end of the season differed significantly between all soil treatments $(\mathrm{CDSC}>\mathrm{PDSC}>$ FVC $>C$ ) and the seedling nitrogen content was higher in fertilised than unfertilised plots $(p=0.04)$. Most of the nitrogen uptake in the fertilised plots of CDSC and PDSC occurred between the samplings in July and September, resulting in significantly higher seedling nitrogen content in fertilised than in unfertilised plots at the harvest on September 7. In unfertilised plots, most of the nitrogen uptake occurred between the harvests in September and March. After the third growing season, the ranking was similar to the first growing season (CDSC > PDSC > FVC > C), while PDSC and FVC were not significantly different after the second growing season. After the second and third growing seasons, the fertilising treatment did not affect seedling nitrogen content significantly.

The seedling nitrogen concentration was lower in CDSC and PDSC during the first growing season, but at the harvest between the first and second growing seasons (March 17 1999), the seedling nitrogen concentration in CDSC was sig- nificantly higher than in other soil treatments (Tab. II). The seedling nitrogen concentrations were lower in CDSC than in other soil treatments after the second and third growing seasons, while seedlings in FVC had the highest nitrogen concentrations. Fertilising increased the seedling nitrogen concentrations significantly at the two measurements during the first growing season and at the measurement in the spring before the second growing season. However, at later measurements seedling nitrogen concentrations were not significantly different between the fertiliser treatments (Tab. II).

The amount of field vegetation was reduced by the soil treatments in the first growing season, and especially in CDSC (Fig. 2, $p<0.0001, \mathrm{C}>\mathrm{FVC}>\mathrm{CDSC}$ ), but during the following two growing seasons the soil treatment did not affect field vegetation amounts significantly. Field vegetation amounts were significantly higher during the third growing season in the fertilised plots $(p=0.01)$, but was not significantly affected during the two previous growing seasons. In CDSC, the field vegetation colonised the fertilised plots much faster than the unfertilised plots, but no significant interaction effects was found. Also the species composition changed as a result of the soil treatments. In FVC, CDSC and in the patches in PDSC the herb Galeopsis tetrahit L. dominated the flora together with Vicia Cracca L. and Cirsium arvene (L.) Scop., but in $\mathrm{C}$ and the undisturbed part of PDSC was dominated by the grasses Deschampsia cespitosa (L.) P. Beauv and Agrostis capillaries $\mathrm{L}$. 
Table III. Inorganic nitrogen $\left(\mathrm{kg} \mathrm{ha}^{-1}\right)$ in the soil in the various treatments.

\begin{tabular}{|c|c|c|c|c|c|c|c|c|c|c|c|c|c|}
\hline \multirow[b]{3}{*}{ Date } & \multirow[b]{3}{*}{ Level } & \multicolumn{6}{|c|}{ Non fertilised } & \multicolumn{6}{|c|}{ Fertilised } \\
\hline & & \multicolumn{2}{|c|}{ CDSC } & \multicolumn{2}{|c|}{ FVC } & \multicolumn{2}{|c|}{$\mathrm{C}$} & \multicolumn{2}{|c|}{ CDSC } & \multicolumn{2}{|c|}{ FVC } & \multicolumn{2}{|c|}{$\mathrm{C}$} \\
\hline & & $\mathrm{NH}_{4}-\mathrm{N}$ & $\mathrm{NO}_{3}-\mathrm{N}$ & $\mathrm{NH}_{4}-\mathrm{N}$ & $\mathrm{NO}_{3}-\mathrm{N}$ & $\mathrm{NH}_{4}-\mathrm{N}$ & $\mathrm{NO}_{3}-\mathrm{N}$ & $\mathrm{NH}_{4}-\mathrm{N}$ & $\mathrm{NO}_{3}-\mathrm{N}$ & $\mathrm{NH}_{4}-\mathrm{N}$ & $\mathrm{NO}_{3}-\mathrm{N}$ & $\mathrm{NH}_{4}-\mathrm{N}$ & $\mathrm{NO}_{3}-\mathrm{N}$ \\
\hline \multirow[t]{2}{*}{980703} & $0-10$ & 3 & 3 & 6 & 1 & 9 & 1 & 14 & 11 & 12 & 4 & 12 & 8 \\
\hline & $10-30$ & 6 & 14 & 5 & 8 & 6 & 1 & 5 & 12 & 6 & 11 & 11 & 4 \\
\hline \multirow[t]{3}{*}{980907} & $0-10$ & 1 & 1 & 7 & 8 & 5 & 2 & 5 & 9 & 38 & 22 & 5 & 3 \\
\hline & $10-30$ & 1 & 17 & 2 & 11 & 3 & 2 & 1 & 14 & 3 & 8 & 2 & 2 \\
\hline & $30-50$ & 2 & 49 & 2 & 17 & 2 & 2 & 1 & 39 & 2 & 8 & 1 & 2 \\
\hline \multirow[t]{3}{*}{990511} & $0-10$ & 1 & 0 & 8 & 3 & 11 & 7 & 1 & 0 & 12 & 6 & 9 & 8 \\
\hline & $10-30$ & 1 & 3 & 5 & 8 & 4 & 8 & 1 & 1 & 3 & 12 & 3 & 11 \\
\hline & $30-50$ & 4 & 6 & 1 & 8 & 1 & 6 & 3 & 5 & 1 & 8 & 1 & 8 \\
\hline \multirow[t]{2}{*}{990630} & $0-10$ & 1 & 0 & 8 & 1 & 6 & 1 & 2 & 3 & 9 & 1 & 6 & 2 \\
\hline & $10-30$ & 3 & 5 & 4 & 2 & 3 & 2 & 1 & 23 & 3 & 1 & 2 & 4 \\
\hline \multirow[t]{2}{*}{990818} & $0-10$ & 0 & 0 & 6 & 2 & 6 & 1 & 1 & 0 & 9 & 2 & 5 & 3 \\
\hline & $10-30$ & 1 & 7 & 5 & 3 & 3 & 2 & 1 & 10 & 3 & 2 & 3 & 8 \\
\hline \multirow[t]{2}{*}{000705} & $0-10$ & 2 & 1 & 15 & 1 & 12 & 1 & 2 & 1 & 21 & 8 & 19 & 3 \\
\hline & $10-30$ & 2 & 4 & 4 & 6 & 4 & 4 & 1 & 2 & 4 & 16 & 5 & 4 \\
\hline \multirow[t]{2}{*}{000817} & $0-10$ & 1 & 0 & 10 & 5 & 8 & 2 & 11 & 20 & 20 & 19 & 12 & 8 \\
\hline & $10-30$ & 1 & 2 & 4 & 4 & 5 & 3 & 4 & 10 & 10 & 41 & 5 & 16 \\
\hline
\end{tabular}

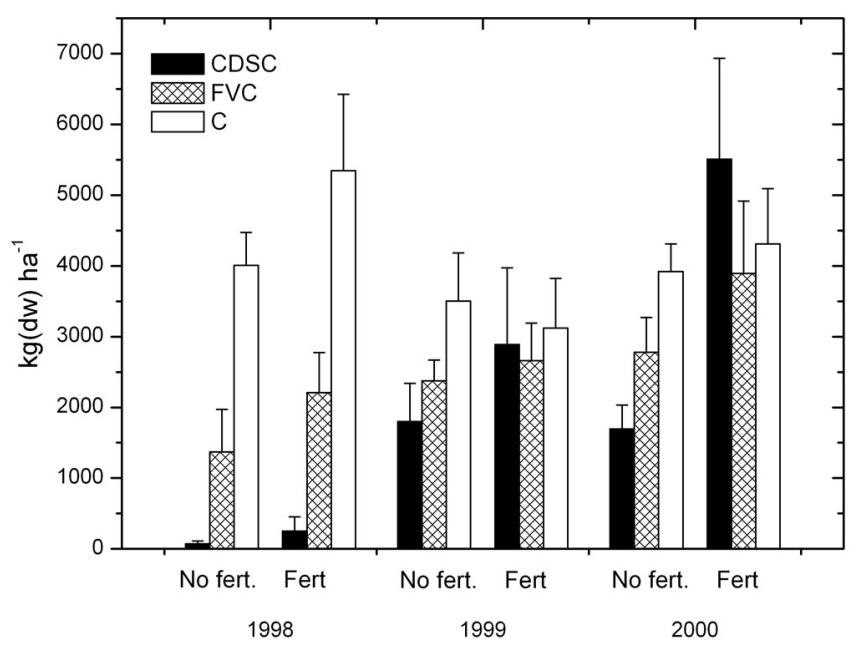

Figure 2. Quantities of living field vegetation (mean $\pm \mathrm{SE}$ ) during the vegetation period. $\mathrm{CDSC}=$ complete deep soil cultivation, $\mathrm{FVC}=$ field vegetation control and $\mathrm{C}=$ control.

Except for the two first samplings in 1998, the available soil nitrogen was slightly lower in CDSC compared to FVC and C (Tab. III). There was more soil inorganic nitrogen available in fertilised plots, except for May 1999 (before fertilising) and the autumn 1999 (when fertilising was cancelled). High levels of inorganic nitrogen were found in the fertilised subplots in FVC in September 1998 - less than two weeks after fertilising -, but no accumulation of nitrogen was detected in the other two treatments. High levels of nitrate were found in the lower part of the profile in CDSC in the autumn 1998 but not in the spring 1999.

Down to $30 \mathrm{~cm}$ depth, FVC and $\mathrm{C}$ had a higher net mineralisation rate than CDSC in both fertilisation regimes on all sampling occasions, except during incubation in the winter 1998/99 when the difference was small (Tab. IV). There was no difference between FVC and $\mathrm{C}$ in mineralisation rates and no difference between fertilising regimes. The potential nitrification was high and almost the entire net mineralisation was nitrified in all treatments.

Nitrogen concentrations in soil water were higher in CDSC than in FVC and C in the late autumn of 1999 and lower in the spring of 1999 (Fig. 3). N concentrations were higher for CDSC than for FVC and C in late autumn 1999, but this was not repeated in 2000. Nitrate dominated in the soil water, but small amounts of organic nitrogen and ammonium occurred in the samples (data not shown).

The soil density in the profile was changed through soil cultivation. Below $20 \mathrm{~cm}$ soil depth the soil density was significantly lower in CDSC than in C and FVC, but for 0-10 $\mathrm{cm}$ soil depth the reverse was observed (Fig. 4). However, the 


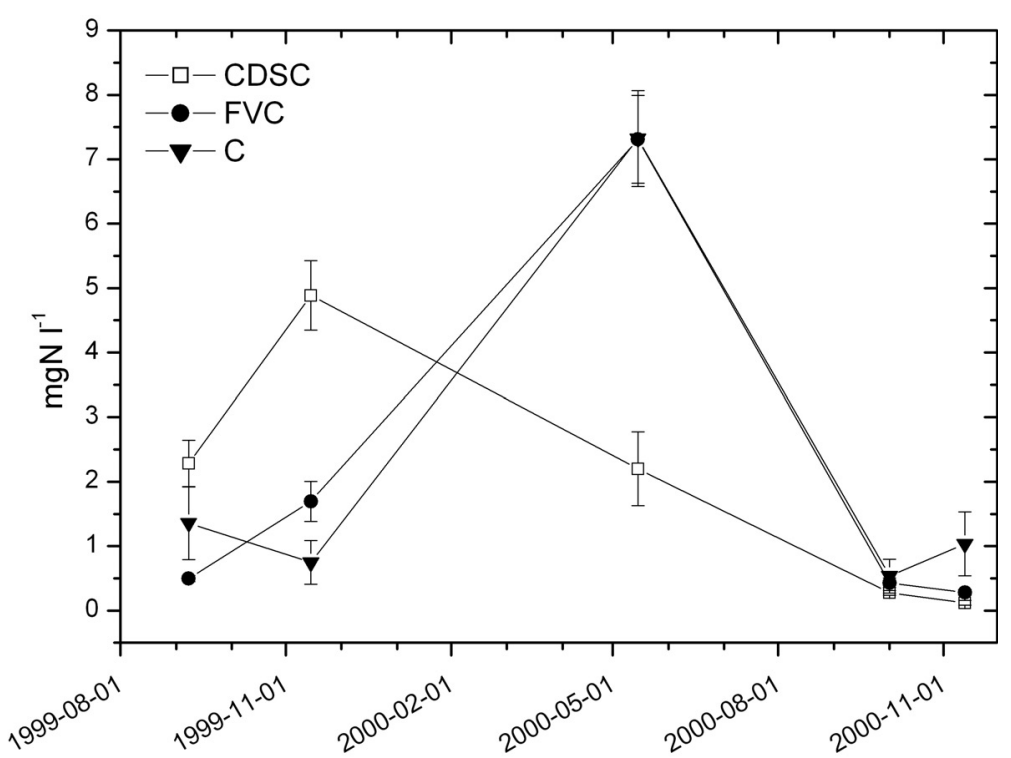

Figure 3. Total nitrogen concentration (organic and inorganic nitrogen) in the soil water (mean $\pm \mathrm{SE}$ ), sampled with suction lysimeters at $60-65 \mathrm{~cm}$ soil depth. $\mathrm{CDSC}=$ complete deep soil cultivation, $\mathrm{FVC}=$ field vegetation control and $\mathrm{C}=$ control.

Table IV. Net mineralisation and potential nitrification $\left(\mathrm{gN} \mathrm{ha}^{-1} \mathrm{day}^{-1}\right)$ in the soil in the various treatments.

\begin{tabular}{|c|c|c|c|c|c|c|c|c|c|c|c|c|c|}
\hline \multirow[b]{3}{*}{ Date } & \multirow[b]{3}{*}{ Level } & \multicolumn{6}{|c|}{ Non fertilised } & \multicolumn{6}{|c|}{ Fertilised } \\
\hline & & \multicolumn{2}{|c|}{ CDSC } & \multicolumn{2}{|c|}{ FVC } & \multicolumn{2}{|c|}{$\mathrm{C}$} & \multicolumn{2}{|c|}{ CDSC } & \multicolumn{2}{|c|}{$\mathrm{FVC}$} & \multicolumn{2}{|c|}{$\mathrm{C}$} \\
\hline & & Net min. & Pot. nitr. & Net min. & Pot. nitr. & Net min. & Pot. nitr. & Net min. & Pot. nitr. & Net min. & Pot. nitr. & Net min. & Pot. nitr. \\
\hline $980703-$ & $-0-10$ & 66 & 63 & 810 & 698 & 2148 & 1721 & 418 & 424 & 1905 & 1479 & 1307 & 1109 \\
\hline 980907 & $10-30$ & -84 & -39 & 328 & 230 & 487 & 536 & 368 & 290 & 712 & 713 & 417 & 520 \\
\hline $980907-$ & $-0-10$ & 93 & 43 & 235 & 211 & 204 & 180 & 48 & 52 & 203 & 280 & 340 & 305 \\
\hline 990428 & $10-30$ & 188 & 156 & 170 & 161 & 180 & 173 & 136 & 133 & 267 & 249 & 199 & 189 \\
\hline $990511-$ & $-0-10$ & 386 & 144 & 802 & 808 & 1065 & 1002 & 126 & 91 & 874 & 868 & 1546 & 1308 \\
\hline 990630 & $10-30$ & 273 & 197 & 347 & 355 & 411 & 391 & 130 & 120 & 391 & 363 & 675 & 631 \\
\hline 990630 & $-0-10$ & 41 & 43 & 798 & 802 & 1262 & 1092 & 403 & 376 & 1017 & 1015 & 1105 & 999 \\
\hline 990818 & $10-30$ & 362 & 350 & 516 & 511 & 447 & 424 & 248 & 221 & 502 & 479 & 488 & 452 \\
\hline 000705 & $-0-10$ & 75 & 21 & 547 & 699 & 682 & 805 & 335 & 245 & 648 & 819 & 1030 & 1134 \\
\hline 000817 & $10-30$ & 42 & 22 & 192 & 197 & 317 & 330 & 280 & 218 & 250 & 272 & 394 & 418 \\
\hline
\end{tabular}

total soil density down to $50 \mathrm{~cm}$ soil depth was $19 \%$ higher in $\mathrm{C}$ and FVC than in CDSC $(p=0.02)$.

The soil water potential was high during the entire growing season of 1998, which was a wet year without any drought periods. The soil water potential was slightly lowered at $10 \mathrm{~cm}$ depth in a dry period in August 1999 and in May 2000 (data not shown). During dry periods, the scarified soil treatments had the lowest potentials. At 30 and $50 \mathrm{~cm}$ soil depth, the soil water potential did not drop significantly and was not lower than $-0.07 \mathrm{MPa}$ in any treatment at any measurement (data not shown).

Voles caused the most serious damage in the experiment. There was great damage in the winter between the first and the second growing seasons. Protection of the seedlings during the second and third growing seasons was efficient and no seedlings were injured after protection. Other damaging agents caused only negligible amounts of severe damage (class 3 and 4 ) or mortality. Between the first and second growing season, $\mathrm{C}$ had 70-80\% severely damaged or dead seedlings, a result which was significantly higher than in any of the other soil treatments (Fig. 5a). In CDSC the damage was below 5\% and mortality was negligible. After the third growing season, most of the severely damaged seedlings had died (Fig. 5b). Fertilising increased severe damage during the first winter $(p=0.015)$ and mortality after three growing seasons $(p=0.014)$. Seedling growth was lower for damaged seedlings than for undamaged 


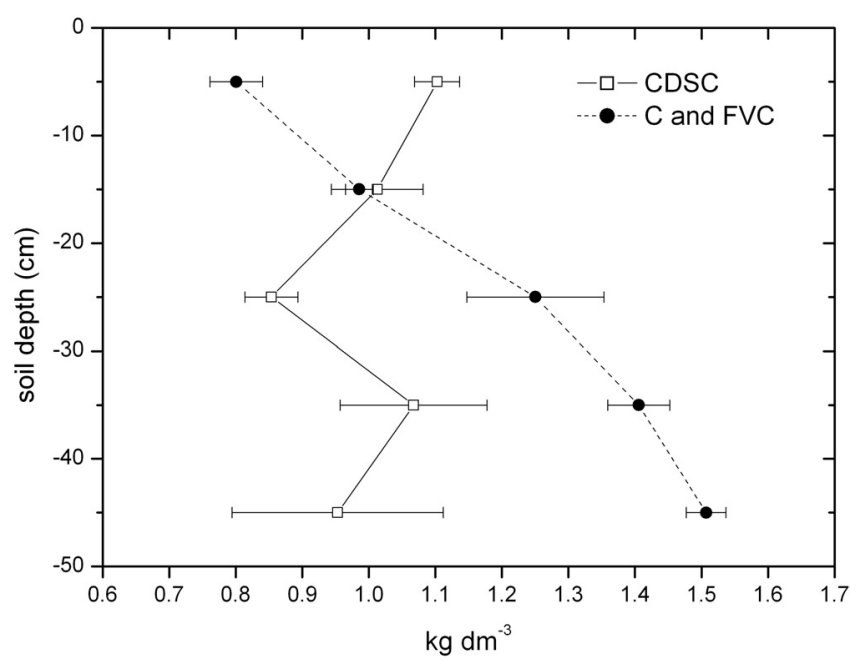

Figure 4. Soil density (mean $\pm \mathrm{SE}$ ) at various soil depths measured during 1999. CDSC = complete deep soil cultivation, $\mathrm{FVC}=$ field vegetation control and $\mathrm{C}=$ control.

seedlings in all soil treatments. After three growing seasons the diameter was $16.5 \mathrm{~mm}$ for class 0 and 1 . For class 2 and 3 the diameter was $15.5 \mathrm{~mm}$ and $13.9 \mathrm{~mm}$, respectively. The figures are weighted mean values since the number of seedlings differed between treatments.

\section{DISCUSSION}

Treatments with soil disturbance (CDSC and PDSC) affected seedling growth positively. Moreover, field vegetation control with herbicides (FVC) was positive although the field vegetation was not completely controlled. In addition, the species composition in the field vegetation layer was changed and FVC became dominated by herbs instead of grasses as in C.

Voles caused the worst damage in the plantation. In addition to mortality, damage by voles reduced the seedling growth for the second and third growing seasons. The mortality and severely damage occurrences were reduced in all soil treatments compared to $\mathrm{C}$, and in CDSC the damage was almost eliminated. The total amount of field vegetation (living and senescent) in the soil treatments was strongly correlated to vole damage (data not shown), since the vegetation provided protection to the voles [1]. Moreover, the reduction in damage and mortality in PDSC compared to $\mathrm{C}$ was significant although the vegetation-free area was small. Since fertilising increased the amount of field vegetation this was probably the cause of increased damage and mortality by vole. Another possible explanation is that voles found the seedlings in the fertilised plots more attractive than the seedlings in the unfertilised plots, since the fertilised seedlings has a higher $\mathrm{N}$ concentration. This correlation was found between needle $\mathrm{N}$ concentration and browsing by roe deer on Norway spruce seedlings [2]. The stem protection device applied to the seedlings between the first and second growing season was effective. No more vole damage occurred after the first winter,

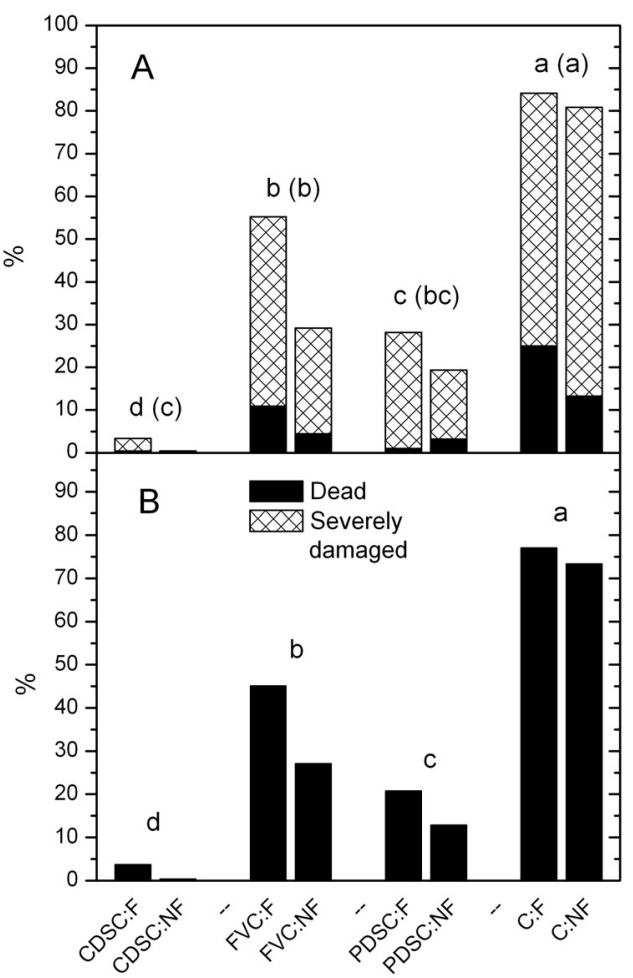

Figure 5. Severely damaged and dead seedlings by voles after the first (A) and third growing season (B). Statistically significant differences between treatments are shown with different letters. Letters within brackets in (A) show statistics for dead seedlings. $\mathrm{CDSC}=$ complete deep soil cultivation, $\mathrm{FVC}=$ field vegetation control, $\mathrm{PDSC}=$ deep soil cultivation in patches and $\mathrm{C}=$ control. $\mathrm{F}=$ fertilised. $\mathrm{NF}=$ unfertilised.

although field vegetation was abundant. The reduction in growth by vole damage was considered the most important factor to the control of seedling growth during the second and third growing seasons.

The seedling biomass increase during the first season was the greatest in soil treatments with the highest net nitrogen uptake. However, although fertilising increased the nitrogen uptake and the seedling nitrogen concentration during the first growing season, growth was not positively affected. The growth during the second growing season was correlated to the seedling nitrogen concentrations in the winter between the first and second growing seasons, which also has been shown by earlier studies $[1,25]$. This correlation might be a result of the retranslocation of $\mathrm{N}$ to growing tissues during the second growing season [17]. However, the nitrogen concentration after the first growing season may also reflect a good environment and successful establishment for the seedlings. This will also have a positive effect on seedling growth during the second growing season.

Our results showed that root growth was more important to seedling net nitrogen uptake in newly planted seedlings than mineralisation or competition. Net nitrogen mineralisation was negatively correlated to seedling nitrogen uptake. However, bulk soil measurement of nutrients does not always correlate 
to nutrient uptake $[18,36]$. Seedlings in treatments with high nitrogen uptake also had large root growth, and root growth has earlier been known to be important to water and nutrient uptake in newly planted seedlings $[4,5]$. Drought is shown to limit root growth and nutrient uptake in conifers $[3,5,15]$ but no drought occurred during the first growing season. Root growth and nitrogen uptake were the highest in the soil treatments that had the lowest soil water potentials in 1999 and 2000 (CDSC and PDSC). However, the soil density was lower in CDSC and probably also in PDSC with a radical soil disturbance compared to FVC and C with undisturbed soil. High root growth occurred in soil treatments with low soil density and might be explained by low root penetration resistance and better aeration $[11,35]$.

The hypothesis that the amount of field vegetation decreased the nitrogen uptake in seedlings could not clearly be confirmed in this study. During the first growing season, the growth and nitrogen uptake was the highest in the treatments with the greatest root growth (CDSC and PDSC). However, in these treatments the amount of field vegetation was so low that there was no significant competition. By contrast, in FVC and $\mathrm{C}$ where the amount of field vegetation was great, the root growth was so low that the seedlings had problems competing for resources in the soil. There was hence no significant competition. This was indicated by the result that there was no dependence between nitrogen uptake and field vegetation amounts in FVC and $\mathrm{C}$, although there were significant differences in field vegetation quantities. During the second growing season there was no difference in field vegetation between treatments, but there were differences in nitrogen uptake. During the third growing season when the fertilising effect on field vegetation quantities was significant, there was no effect on nitrogen uptake between fertiliser treatments. These results were especially clear in CDSC where the difference in field vegetation in the two fertiliser regimes was great, but there was no difference in nitrogen uptake. Since inorganic nitrogen amounts were slightly higher in FVC compared to $\mathrm{C}$ in unfertilised plots (except in May 1999), field vegetation seems to be able to reduce the pool of exchangeable inorganic nitrogen in the soil [26]. This may affect seedling nitrogen uptake negatively.

The hypothesis that fertilising was positive to seedling growth when field vegetation is controlled was difficult to evaluate, since FVC and CDSC were colonised rapidly. However, during the first growing season when the field vegetation amounts were different in the treatments, the seedling biomass increase was greater in FVC than in C. High field vegetation amounts caused by fertilising resulted in lower growth in all soil treatments except for PDSC after three growing seasons.

The difference in nitrogen concentration in the soil water between CDSC and FVC and $\mathrm{C}$ might be a result of different activity levels of the decomposers in the soil organic matter. The cooling of the soil in autumn starts at the top of the soil profile, and since the soil organic matter in the CDSC is buried in the soil, the activity of decomposers will probably continue at higher rates for a longer time in the autumn and winter [8, 16, 37-39]. Differences in soil temperature may also explain the higher soil water nitrogen concentrations in FVC and $\mathrm{C}$ in the spring, since the warming of the soil also starts from the top, where the soil organic matter was located in these treatments. Precipitation was high during the winter of 1999/2000
(845 mm October to March at Torup, the closest weather station) and the soil was unfrozen except for some short periods. This resulted in a high flow of soil water since the evapotranspiration is low during the winter months [31, 38, 39]. The risk of nitrogen leaching was therefore high in CDSC during the winter months, since both soil water flow and nitrogen concentrations in the soil water in CDSC were higher during this period than in $\mathrm{C}$ and FVC. By contrast, the soil water flow was low during the vegetation season (approx. April to September) since transpiration was high (approx. $400 \mathrm{~mm}$, [31]) and precipitation was low (685 mm 1999 and $497 \mathrm{~mm} 2000$ at Torup, $[38,39])$. This was also confirmed by the unsuccessful soil water sampling during the summers. Therefore, the risk of nitrogen leaching during the vegetation period, when the nitrogen concentration in the soil water was high, for FVC and $\mathrm{C}$ was lower than during the winter. In the PDSC only $16 \%$ of the soil was disturbed, which means that the nitrogen leaching from this treatment probably was in the same magnitude as $\mathrm{C}$ and FVC. Conclusively, these results indicate an elevated risk for increased nitrogen leaching in CDSC compared to C, FVC and PDSC. However, the elevated nitrogen concentration in the soil water was not repeated in CDSC during the second winter. Moreover, results from earlier studies on nitrogen leaching by soil scarification are in contradiction to these findings [29, 33], but these scarifications were of a lower intensity than CDSC in this study.

\section{CONCLUSIONS}

Intensive site preparations like complete deep soil cultivation proved an effective means to increase seedling growth and reduce seedling damage during establishment. Inversion of the soil profile in patches and field vegetation control with herbicides were not as efficient as complete deep soil cultivation, but had both higher growth and survival than the untreated control. Root growth was enhanced in treatments with soil cultivation during the first season. Seedling nitrogen uptake was higher in the fast growing treatments and nitrogen uptake was positively correlated to fast root development during the establishment season, but high bulk soil nitrogen mineralisation was not an explanatory factor. Fertilising increased the field vegetation colonisation rate after cultivation. Moreover, seedling damage was correlated to the amount of field vegetation, and seedling damage lowered seedling growth. The growth during the first growing season was controlled by nitrogen uptake in the seedlings, but the reduction in growth by vole damage probably to a great extent explains the difference in growth between the treatments in the second and third growing season. The risk of nitrogen leaching is probably higher in complete deep soil cultivation than in other treatments.

Acknowledgements: We thank Rolf Övergaard and the staff at Tönnersjöheden experimental forest for technical support and Petter Oscarsson at the Department of Plant Breeding Research, SLU for access to laboratory facilities. We are also grateful to Torkel Welander at the Southern Swedish Forest Research Centre, SLU and Göran Hallsby at the Department of Silviculture, SLU for valuable comments on the manuscript. The Fibre Forestry Program, Knut and Alice Wallenbergs Foundation, StoraEnso and The Southern Swedish Forest Research Program, financed the experiment. 


\section{REFERENCES}

[1] Bärring U., Studier av metoder för plantering av gran och tall på åkermark i södra och mellersta Sverige (Studies of methods employed in the planting of Picea abies (L.) Karst. and Pinus sylvestris L. on farm land in southern and central Sweden), (in Swedish with English summary), Stud. For. Suec. 50 (1967) 1-332.

[2] Bergquist J., Örlander G., Browsing damage by roe deer on norway spruce seedlings planted on clearcuts of different ages. 2. Effect of seedling vigour, For. Ecol. Manage. 105 (1998) 295-302.

[3] Brissette J.C., Chambers J.L., Leaf water status and root system water flux of shortleaf pine (Pinus echinata Mill.) seedlings in relation to new growth after transplanting, Tree Physiol. 11 (1992) 289-303.

[4] Burdett A.N., Herring L.J., Thompson C.F., Early growth of Norway spruce, Can. J. For. Res. 14 (1984) 644-651.

[5] Burdett A.N., Physiological processes in plantation establishment and the development of specifications for forest planting stock, Can. J. For. Res. 20 (1990) 415-427.

[6] Coutts M.P., Growth of Sitka spruce seedlings with roots divided between soils of unequal matric potential, New Phytol. 92 (1982) 49-61.

[7] Esala M.J., Changes in the extractable ammonium- and nitratenitrogen contents of soil samples during freezing and thawing, Commun. Soil Sci. Plant Anal. 26 (1995) 61-68.

[8] Fitzpatrick E.A., An introduction to soil science, Second ed., Longman Scientific and Technical, Harlow, ISBN 0-582-30128-9, $1986,255 \mathrm{p}$.

[9] Fleming R.L., Black T.A., Eldridge N.R., Effects of site preparation on root zone soil water regimes in high-elevation forest clearcuts, For. Ecol. Manage. 68 (1994) 173-188.

[10] Grossnickle S.C., Heikurinen J., Site preparation: Water relations and growthof newly planted jack pine and white spruce, New For. 3 (1989) 99-123.

[11] Hildebrand E.E., Der Enfluss der Bodenverdichtung auf die Bodenfunktionen im forstlichen Standort, Forstw. Cbl. 102 (1983) $111-125$.

[12] Högbom L., Nilsson U., Örlander G., Nitrate dynamics after clear felling monitored by in vivo nitrate reductase activity (NRA) and natural ${ }^{15} \mathrm{~N}$ abundance of Deschampsia flexuosa (L.), Trin., For. Ecol. Manage. 160 (2002) 273-280.

[13] Imo M., Timmer V.R., Vector competition analysis of black spruce seedling responses to nutrient loading and vegetation control, Can. J. For. Res. 29 (1999) 474-486.

[14] Johansson M.-B., The influence of soil scarification on the turnover rate of slash needles and nutrient release, Scand. J. For. Res. 9 (1994) 170-179.

[15] Kozlowski T.T., Soil moisture and absorption of water by tree roots, J. Arboric. 13 (1987) 39-46.

[16] Lomander A., Kätterer T., Andrén O., Carbon dioxide evolution from top- and subsoil as affected by moisture and constant and fluctuating temperature, Soil Biol. Biochem. 30 (1998) 2017-2022.

[17] Malik V., Timmer V.R., Growth, nutrient dynamics, and interspecific competition of nutrient-loaded black spruce seedlings on a boreal mixedwood site, Can. J. For. Res. 26 (1996) 1651-1659.

[18] Marschner H., Mineral nutrition of higher plants, Academic Press Limited, London, ISBN 0-12-473543-6, 1995.

[19] Margolis H.A., Brand D.G., An ecophysiological basis for understanding plantation establishment, Can. J. For. Res. 20 (1990) 375-390.

[20] Munson A.D., Bernier P.Y., Comparing natural and planted black spruce seedlings. II. Nutrient uptake and efficiency of use, Can. J. For. Res. 23 (1993) 2435-2442.
[21] Nambiar E.K.S., Sands R., Competition for water and nutrients in forests, Can. J. For. Res. 23 (1993) 1955-1968.

[22] Neckelmann J., To foryngelsefors øg i rødgran på midtjysk hedeflade. Skovbrugsserien, forskningscentret for skov og landskab, 16 (1995) 1-180 (in Danish).

[23] Norberg G., Steam treatment of forest ground vegetation to improve tree seedling establishment and growth, Doctoral thesis, Swedish University of Agricultural Sciences, Silvestria 170 (2001) $1-19$.

[24] Nilsson U., Gemmel P., Hällgren J-.E., Competing vegetation effects on initial growth of planted Picea abies, N. Z. J. For. Sci. 26 (1996) 84-98.

[25] Nilsson U., Örlander G., Vegetation management on grassdominated clearcuts planted with Norway spruce in southern Sweden, Can. J. For. Res. 29 (1999) 1015-1026.

[26] Nilsson U., Örlander G., Response to newly planted Norway spruce seedlings to fertilization, irrigation and herbicide treatments, Ann For. Sci. 60 (2003) 637-643.

[27] Örlander G., Gemmel P., Hunt J., Site preparation, A Swedish overview, FRDA report 105 (1990) 1-57.

[28] Örlander G., Egnell G., Albrektsson A., Long-term effects of site preparation on growth in Scots pine, For. Ecol. Manage. 86 (1996) 27-37.

[29] Örlander G., Langvall O., Petersson P., Westling O., Arealförluster av näringsämnen efter ristäkt och markberedning på sydsvenska hyggen, Arbetsrapport 15 (1997), Institutionen för Sydsvensk Skogsvetenskap, SLU (in Swedish).

[30] Örlander G., Hallsby G., Gemmel P., Wilhelmsson C., Inverting improves establishment of Pinus contorta and Picea abies - 10-year results from a site preparation trial in northern Sweden, Scand. J. For. Res. 13 (1998) 160-168.

[31] Persson G., Comparison of simulated water balance for willow, spruce, grass ley and barley, Nord. Hydrol. 28 (1997) 85-98.

[32] Raison R.J., Connell M.J., Khanna P.K., Methodology for studying fluxes of soil mineral-N in situ, Soil Biol. Biochem. 19 (1987) 521530.

[33] Ring E., Effects of previous $\mathrm{N}$ fertilizations on soil-water $\mathrm{pH}$ and $\mathrm{N}$ concentrations after clear-felling and soil scarification at a Pinus sylvestris site, Scand. J. For. Res. 11 (1996) 7-16.

[34] Rook D.A., Swanson R.H., Cranswick A.M., Reaction of radiata pine to drought, in: Proceedings of soil and plant water symposium 1976, Information series, New Zealand department of science and industrial research, No. 126, ISSN 077-9636, 1977, pp. 55-68.

[35] Ross S.M., Malcolm D.C., Effects of intensive forestry cultivating practices on upland heath soils in south-east Scotland, Forestry 55 (1982) 155-171.

[36] Smethurst P.J., Soil solution and other soil analyses as indicators of nutrient supply: a review, For. Ecol. Manage. 138 (2000) 397-411.

[37] SMHI. Väder och vatten. Swedish meteorological and hydrological institute, Norrköping, 1998 (in Swedish).

[38] SMHI. Väder och vatten. Swedish meteorological and hydrological institute, Norrköping, 1999 (in Swedish).

[39] SMHI. Väder och vatten. Swedish meteorological and hydrological institute, Norrköping, 2000 (in Swedish).

[40] Tamm C.O., Nitrogen in terrestial ecosystems: Questions of productivity, vegetational changes and ecosystem stability, Ecol. Stud. 81, ISBN 3-540-51807-X, 1991, 115 p.

[41] Thiffault N., Jobidon R., Munson A.D., Performance and physiology of large containerized and bare-root spruce seedlings in relation to scarification and competition in Québec (Canada), Ann. For. Sci. 60 (2003) 645-655.

[42] Zar J., Biostatistical analysis, Prentice-Hall Inc., New Jersey, USA, 1986. 